\title{
Effect of pH and sodium chloride on the viscosity of skim milk retentates
}

\author{
M.H. ABD EL-SALAM, S. EL-SHIBINY, M.B. MAHFOUZ \\ and H.F. EL-DEIN \\ Laboratory of Food Technology and Dairying, National Research Centre \\ Dokki, Cairo, Egypt
}

\section{Summary}

Skim milk retentates of different protein and $\mathrm{NaCl}$ contents were inoculated with $1-10 \%$ of mixed starter of $L$. bulgaricus and $S$. thermophilus $(1: 1)$ and incubated at $37^{\circ} \mathrm{C}$. The relative viscosities of these retentates were followed as a function of changes in $\mathrm{pH}$ and added $\mathrm{NaCl}$.

The relative viscosity of retentate was affected by its protein content, $\mathrm{NaCl}$ added and $\mathrm{pH}$. The relative viscosity of retentate increased with the increase in its protein content ( 4 to $17.3 \%$ ) but the relation was non-linear.

Addition of $1 \% \mathrm{NaCl}$ to retentate increased its relative viscosity, that decreased on standing or addition of higher percentage of $\mathrm{NaCl}(2$ and $3 \%)$. The relative viscosity of retentate gradually decreased with the decrease in $\mathrm{pH}$, followed by reincrease at $\mathrm{pH}$ less than 6.00 . The $\mathrm{pH}$ at which the relative viscosity began to reincrease was dependant on the percentage of added $\mathrm{NaCl}$.

Key words : Relative viscosity - Retentate - Skim milk - Sodium chloride - Starter $\mathrm{pH}$ - Protein content.

\section{Résumé}

'nfluence du pH et du chlorure de sodium sur la viscosité de rétentats de lait écrémé

Des rétentats de lait écrémé de différentes teneurs en protéines et $\mathrm{NaCl}$ ont été ensemencés avec 1-10\% de levains mixtes de $L$. bulgaricus et $S$. thermophilus $(1: 1)$ et incubés à $37^{\circ} \mathrm{C}$.

Les viscosités relatives de ces rétentats ont été suivies en fonction des variations du $\mathrm{PH}$ et du $\mathrm{NaCl}$ ajouté.

La viscosité relative du rétentat est influencée par sa teneur en protéines, l'addition de $\mathrm{NaCl}$ et le $\mathrm{pH}$. Elle augmente avec l'augmentation de la teneur en protéines (4 à $17,3 \%$ ), mais la relation est non linéaire. 
L'addition de $1 \%$ de $\mathrm{NaCl}$ au rétentat augmente dans un premier temps sa viscosité relative, mais celle-ci diminue ensuite au cours de la conservation. L'ajout d'un pourcentage plus élevé de $\mathrm{NaCl}(2$ et $3 \%$ ) décroît également la viscosité relative.

Cette caractéristique physique du rétentat diminue également graduellement avec la baisse du $\mathrm{pH}$ mais réaugmente à $\mathrm{pH}$ inférieur à 6,0 . Le $\mathrm{pH}$ auquel la viscosité relative commence à croître est dépendant du pourcentage de $\mathrm{NaCl}$ ajouté.

Mots clés : Viscosité relative - Rétentat - Lait écrémé - Chlorure de sodium - Levain $\mathrm{pH}$ - Teneur en protéines.

\section{Introduction}

Viscosity is one of the important characteristics of fluids which determine their mass and heat transfer properties. The viscosity of milk has received attention by several investigators and adequate information on this subject has been reviewed (JENNESS et al., 1974).

The viscosity of concentrated milks and ultrafiltration retentates has received much less attention than milk. The fast increase in the use of ultrafiltration in dairy industry makes it necessary to study the properties of the resulting fluids particularly UF retentates. The viscosity of UF retentates and factors affecting it are of great importance as the viscosity of retentates is rapidly increased with the increase in protein content (CuLIOLI et al., 1974). Therefore, the viscosity of retentate partially determine the concentration factor that can be reached during ultrafiltration processing, and the behaviour of retentates during processing. The effect of protein content and temperature on the viscosity of retentates have been studied (Culioli et al., 1974; Pierre et al., 1978).

Determination of viscosity of retentates of high protein content is tedious and need proper selection of methodology. However, the relative viscosity offers a more simple tool for comparative studies and changes in viscosity as affected by different factors.

The present paper deals with the relative viscosity of UF retentates as affected by protein content, addition of $\mathrm{NaCl}$ and changes in $\mathrm{pH}$ as a result of growth of starter bacteria.

\section{Materials and methods}

\section{A. Preparation of $U F$ retentates}

Skim milk powder (Dairy Crest, UK) was reconstituted in deionized water at the rate of $10 \%$ and ultrafiltered at $45{ }^{\circ} \mathrm{C}$ and 3.6 and 0.6 bar inlet and outlet pressure respectively using DDS Lab 20 UF unit and GR61P membrane. The protein content of the retentate was found to be $17.3 \%$. The retentate was diluted with suitable quantities of permeate to obtain retentates with 12,8 , and $4 \%$ protein respectively. $\mathrm{NaCl}$ was added to the prepared retentates at the rate of $0,0.5,1.0,2.0$ and $3.0 \%$ respectively directly before inoculation with starter. 


\section{B. Inoculation with starter}

Pure strains of Lactobacillus bulgaricus and Streptococcus thermophilus were obtained from Ch. Hansen A/S (Copenhagen, Denmark) and they were propagated in sterilized skim milk. Retentates were inoculated with a mixed starter of the two organisms $(1: 1)$ at the rate of $0,1,2,3,5$ and $10 \%$ respectively and incubated at $37^{\circ} \mathrm{C}$ for $8 \mathrm{~h}$ or until curdled. The relative viscosity and $\mathrm{pH}$ of these retentates were followed at $2 \mathrm{~h}$ intervals.

\section{Determination of relative viscosity}

The viscosity of retentate was determined relative to that of the corresponding permeate using Hoppler viscosimeter. $\mathrm{NaCl}$ was added to permeate at the rate of $0,0.5,1,2$ and $3 \%$ respectively. The time taken by the falling ball in retentate was divided by that taken in permeate containing the same $\mathrm{NaCl}$ content. Measurements were carried out at $37^{\circ} \mathrm{C}$. The $\mathrm{pH}$ was determined in the retentates using a $\mathrm{pH}$ meter with combined electrode.

\section{Results and discussion}

Figure 1 shows the changes in $\mathrm{pH}$ of skim milk retentates as a function of percentage of starter and $\mathrm{NaCl}$ added, and incubation time. These results indicate that the $\mathrm{pH}$ of retentate decreased with the increase in percentage of starter added. A linear relation was evident between the $\mathrm{pH}$ and the log percentage of starter

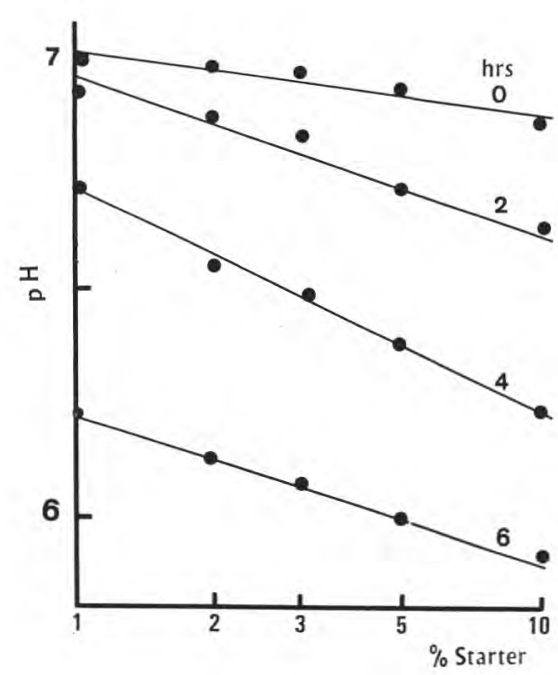

Fig. 1

$p H$ changes as a function of the percentage of added starter and incubation time for retentate containing $12 \%$ protein.

Changements de $p H$ en fonction du pourcentage de levain ajouté et du temps d'incubation d'un rétentat à $12 \%$ de protéines. 


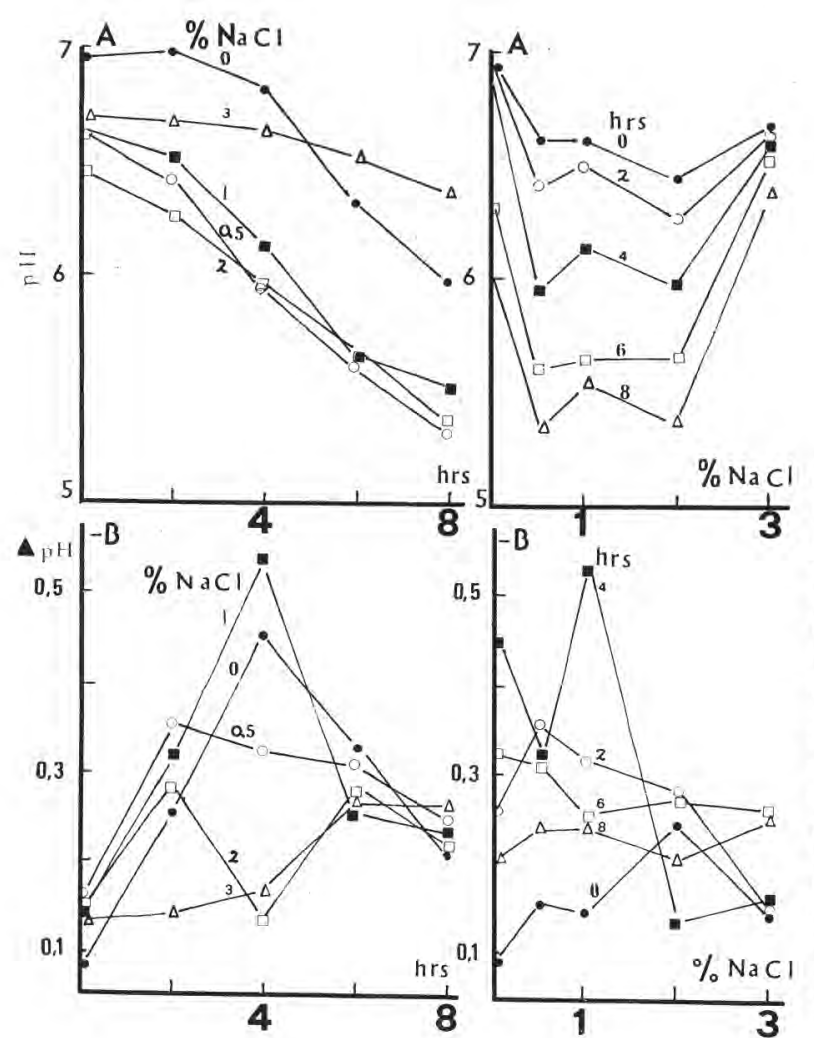

Fig. 2

Coefficient $A$ and $B$ from the equation (1) as a function of $\mathrm{NaCl}$ and incubation time for the retentates containing $17.3 \%$ protein : 0 time, $0 \mathrm{NaCl}$; $02 \mathrm{hr}$, $0.5 \% \mathrm{NaCl}$; $4 \mathrm{hr}, 1 \% \mathrm{NaCl}$; ㅁ $6 \mathrm{hr}, 2 \% \mathrm{NaCl} ; \triangle 8 \mathrm{hr}, 3 \%$ $\mathrm{NaCl}$.

Coefficients $A$ et $B$ de l'équation (1) en fonction du $\mathrm{NaCl}$ ajouté et du temps d'incubation pour des rétentats contenant $17,3 \%$ de protéines : - sans ajout de $\mathrm{NaCl}$, sans incubation; 0 incubation $2 \mathrm{~h}, 0,5 \% \mathrm{NaCl}$;

- incubation $4 \mathrm{~h}, 1 \% \mathrm{NaCl}$; 口 incubation $6 \mathrm{~h}, 2 \% \mathrm{NaCl}$; $\triangle$ incubation $8 \mathrm{~h}, 3 \% \mathrm{NaCl}$.

added to retentate containing $12 \%$ protein (fig. 1). The relation between the $\mathrm{pH}$ and the log percentage of starter added was expressed using the equation

where

$$
\mathrm{pH}=\mathrm{A}+\mathrm{B} \log \mathrm{S}
$$

$\mathrm{A}=\mathrm{pH}$ value calculated by the least square method for $1 \%$ starter,

$\mathrm{B}=\mathrm{pH}$ decrease when $\%$ of starter added is increased 10 times,

$\mathrm{S}=$ percentage of starter added.

Figures 2 and 3 show the coefficients $\mathrm{A}$ and $\mathrm{B}$ for $\mathrm{pH}$ changes in retentates containing 12 and $17.3 \%$ protein as a function of percentage of $\mathrm{NaCl}$ added and incubation time. These results indicate :

- Within the limits of standard deviation, there was no difference between the retentates containing 12 and $17.3 \%$ protein as to their $\mathrm{pH}$ changes in relation to percentage of starter and $\mathrm{NaCl}$ added and incubation time. This suggest that the starter bacteria grow equally in 12 and $17.3 \%$ protein retentates under the mentioned conditions.

- There is a steady decrease in the A value with the incubation time while the $\mathrm{B}$ value increased to a maximum at $4 \mathrm{~h}$ and slightly decreased thereafter. 

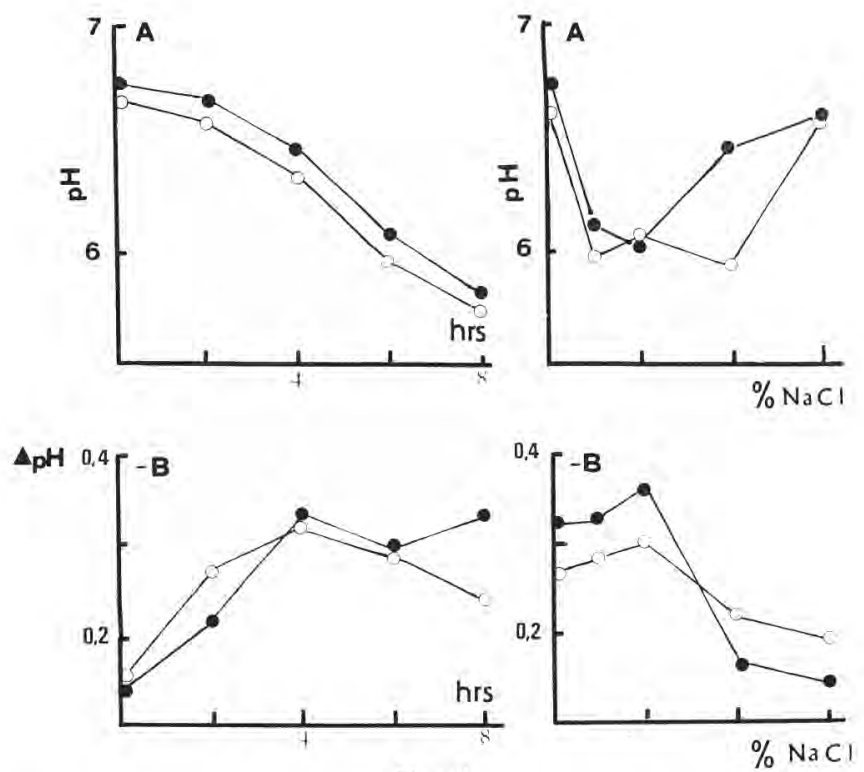

Fig. 3

Average values of coefficients $A$ and $B$ from equation (1) as function of percentage of $\mathrm{NaCl}$ and incubation time for retentates containing $12(0)$ and $17.3 \%(\bullet)$ protein.

Valeurs moyennes des coefficients $A$ et $B$ de l'équation (1) en fonction du pourcentage de $\mathrm{NaCl}$ ajouté et du temps d'incubation pour des rétentats contenant $12 \%(0)$ et $17,3 \%$ (•) de protéines.

- The coefficient A decrease on addition of small percentage of $\mathrm{NaCl}$ and reincrease with further addition of $\mathrm{NaCl}$. This decrease could be explained on exchange of $\mathrm{Na}^{+}$with $\mathrm{H}^{+}$in $\mathrm{NH}_{3}{ }^{+}$group on the protein moiety setting free proton and decreasing $\mathrm{pH}$ (LING, 1963). Further increase in $\mathrm{NaCl}$ added would retard bacterial growth and acid production. Addition of $\mathrm{NaCl}$ up to $1 \%$ had no significant effect on the coefficient B, but it decreased with further increase in $\mathrm{NaCl}$ added indicating retarded bacterial growth and acid development.

The changes in the viscosity of retentate as affected by addition of $\mathrm{NaCl}$ and growth of starter bacteria were followed by determining the relative viscosity to that of permeate. $\mathrm{NaCl}$ was added to permeate at the same percentage added to the tested retentate in order to correct for the direct contribution of added $\mathrm{NaCl}$ to viscosity. Addition of $\mathrm{NaCl}$ slightly increased the viscosity of permeate and linear relation was found between the amount of added $\mathrm{NaCl}$ and viscosity of permeate.

Results illustrated in figure 4 clearly indicate that the relative viscosity of retentate was greatly affected by their protein content and that this relation was not linear. The same was apparent between the relative viscosity of retentate containing $17.3 \%$ protein and the percentage of starter added. Addition of 1 and $10 \%$ starter (3.5\% protein) inoculum would lower the protein content of $17.3 \%$ protein retentate by 0.14 and $1.4 \%$ respectively and in turn its relative 


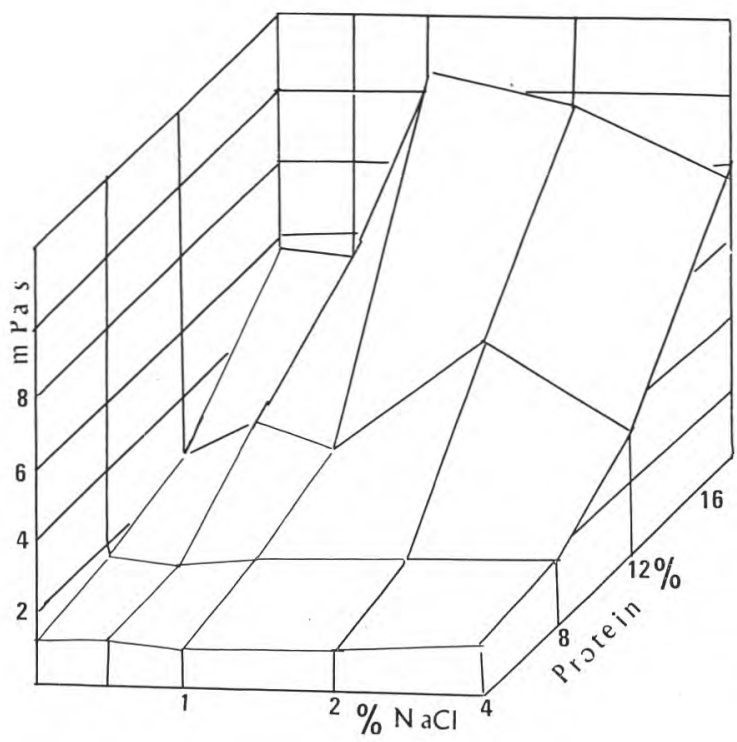

Fig. 4

Viscosity of milk retentates as a function of percentage of salt added and protein concentration.

Viscosité des rétentats de lait en fonction du pourcentage de $\mathrm{NaCl}$ ajouté et de la concentration en protéines.

viscosity. However, this relation was found linear on the basis of $\log$ viscosity and log starter percentage added (fig. 5). The same relation was also obtained in retentate with low protein content $(12 \%)$ (fig. 5). The relation between the relative viscosity and the percentage of stater added was expressed using the equation:

where

$$
\log \text { relative viscosity }=A+B \log S
$$

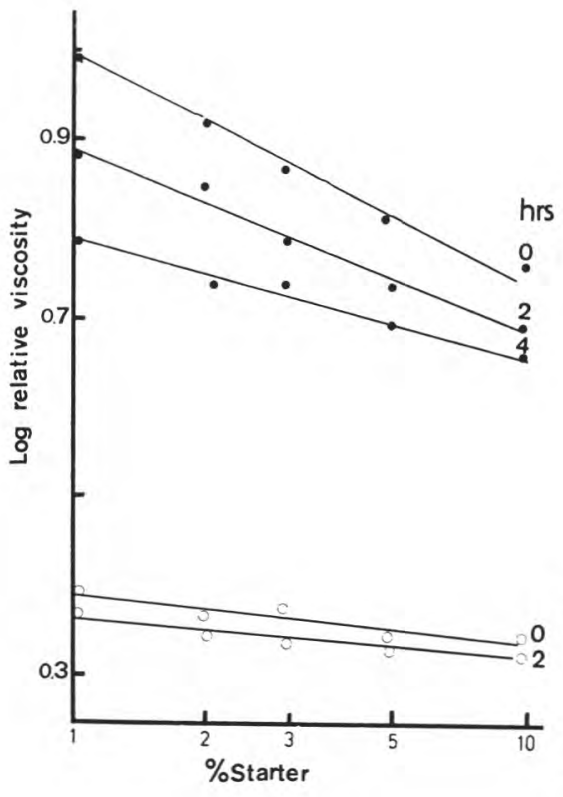

\section{Fig. 5}

Changes in relative viscosity of retentates containing 12 (O) and $17.3 \%$ (•) protein as a function of added starter and incubation time.

Changements de viscosité relative des rétentats contenant $12 \%$ (0) et 17,3\% (•) de protéines en fonction du levain ajouté et du temps d'incubation. 

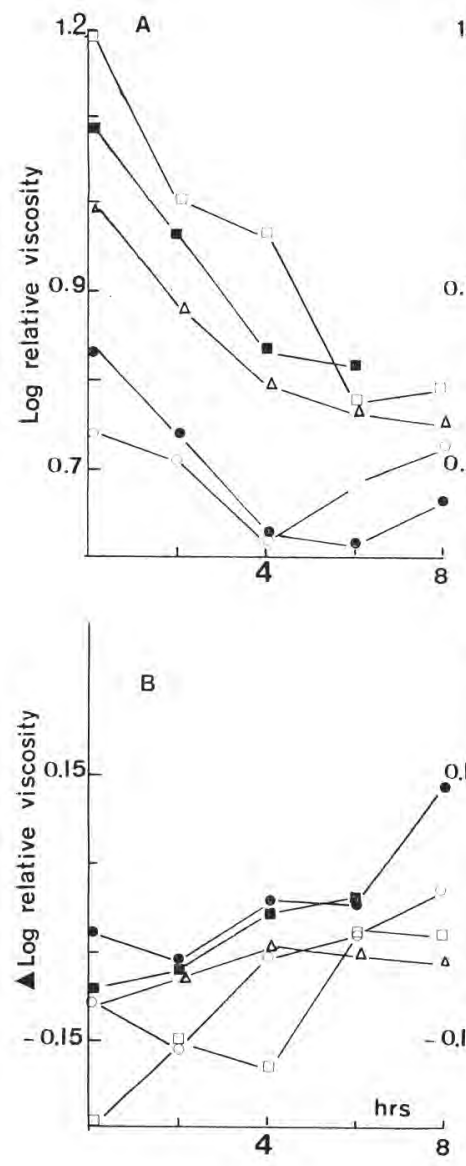

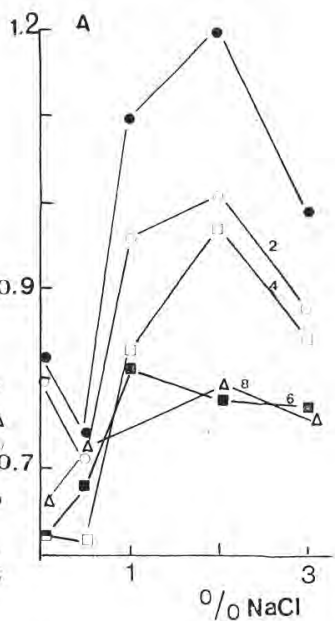

B

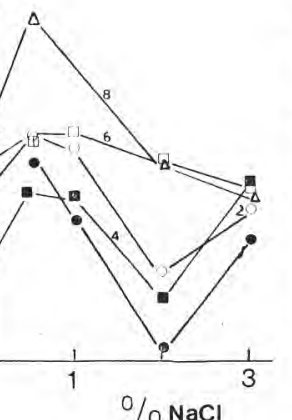

Coefficients $A$ and $B$ from the equation (2) as a function of $\mathrm{NaCl}$ and incubation time for retentates containing $17.3 \%$ protein : 0 time, $0 \mathrm{NaCl} ; 02 \mathrm{hr}$, $0.5 \% \mathrm{NaCl}$; $4 \mathrm{hr}, 1 \% \mathrm{NaCl}$; ㅁ $6 \mathrm{hr}, 2 \% \mathrm{NaCl} ; \triangle 8 \mathrm{hr}, 3 \%$ $\mathrm{NaCl}$.

Coefficients $A$ et $B$ de l'équation (2) en fonction du pourcentage de $\mathrm{NaCl}$ ajouté et du temps d'incubation pour des rétentats contenant $17,3 \%$ de protéines : - sans incubation, sans ajout de $\mathrm{NaCl} ; 02 \mathrm{~h}$ d'incubation, $0,5 \%$ $\mathrm{NaCl}$; $4 \mathrm{~h}$ d'incubation, $1 \%$ $\mathrm{NaCl}$; $6 \mathrm{~h}$ d'incubation, $2 \%$ $\mathrm{NaCl} ; \triangle 8 \mathrm{~h}$ d'incubation, $3 \%$ $\mathrm{NaCl}$.

$\mathrm{A}=\log$ relative viscosity calculated by the least square method for $1 \%$ starter added, 10 times,

$\mathrm{B}=$ decrease in $\log$ relative viscosity with $\%$ starter added is increased

$\mathrm{S}=$ percentage of starter added.

Figures 6 and 7 show changes in coefficient A and B for log relative viscosity in retentate containing 17.3 and 17,3 and $12 \%$ protein respectively as a function of percentage of $\mathrm{NaCl}$ added and in incubation time. The results indicate :

- The changes in relative viscosity in retentates containing 12 and $17.3 \%$ protein follow the same trend of variation as affected by $\mathrm{NaCl}$ added and incubation time. A steady decrease in the A value with incubation time to a minimum at $6 \mathrm{~h}$ and reincreased thereafter. The $\mathrm{B}$ value increased steadly during incubation.

- The coefficient A steadly increased on addition of increased quantities of $\mathrm{NaCl}$ in $12 \%$ protein retentates, while in $17.3 \%$ protein retentate, coeffi- 

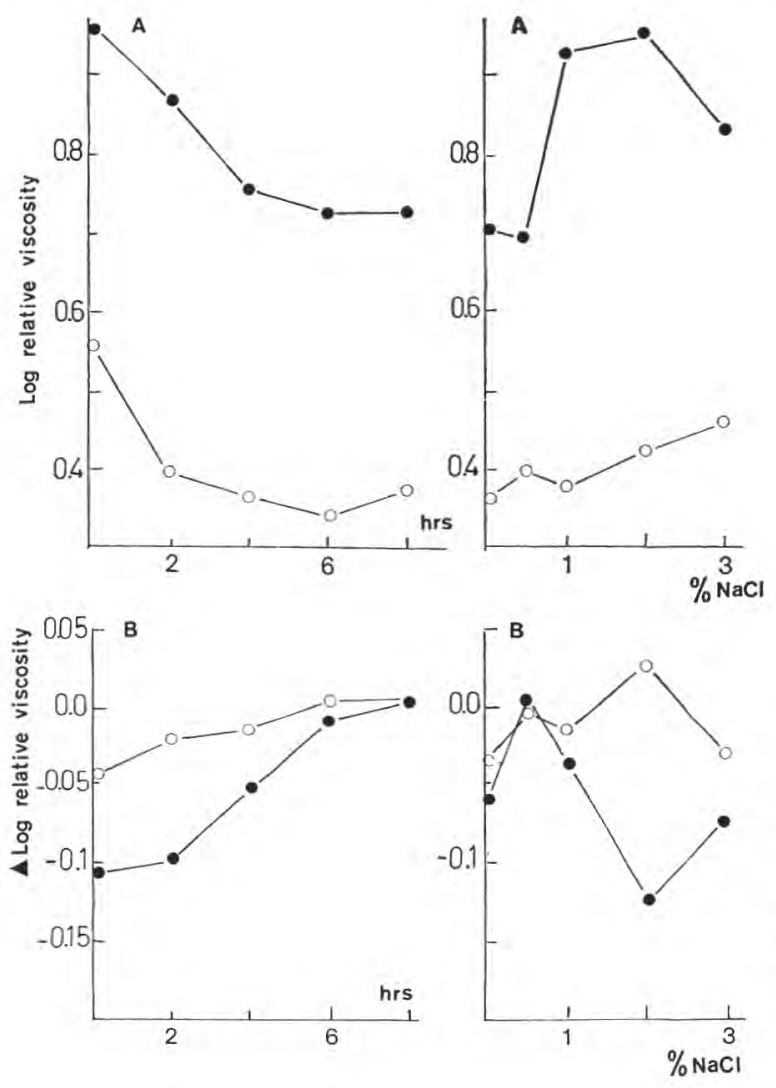

Fig. 7

Average values of coefficient $A$ and $B$ from equation (2) as functions of percentage of $\mathrm{NaCl}$ and incubation time for retentates containing $12(0)$ and $17.3 \%(\bullet)$.

Valeurs moyennes des coefficients $A$ et $B$ de l'équation (2) en fonction du pourcentage de $\mathrm{NaCl}$ ajouté et du temps d'incubation pour des rétentats contenant $12 \%(0)$ et $17,3 \%(\bullet)$ de protéines.

cient $\mathrm{A}$ increased with the addition of $\mathrm{NaCl}$ up to $2 \%$ and then redecreased slightly. Addition of $0.5 \% \mathrm{NaCl}$ slightly increased coefficient $\mathrm{B}$, followed by decrease on further addition of $\mathrm{NaCl}(2 \% \mathrm{NaCl}$ in $17.3 \%$ protein retentate) and reincreased at $3 \% \mathrm{NaCl}$. The changes in $\mathrm{B}$ value in $12 \%$ protein retentates were slightly different from $17.3 \%$ protein retentate.

The effect of $\mathrm{NaCl}$ on the relative viscosity of retentates can be explained on the basis that the action of $\mathrm{NaCl}$ on the colloidal system of milk is a slow reaction that need time to reach equilibrium. The obtained results suggest that $\mathrm{NaCl}$ may have the following effects on the colloidal system of milk :

1. Immediately after the addition of $\mathrm{NaCl}, \mathrm{Na}^{+}$would exchange with the cations on the surface of the casein micelles without any disruption in the casein micelle structure. The formed $\mathrm{Na}-\mathrm{Ca}$ caseinate would increase the hydration of the protein particles and the relative viscosity of retentate.

2. Further contact of $\mathrm{NaCl}$ with the colloidal system would exchange more $\mathrm{Ca}^{++}$for $\mathrm{Na}^{+}$. At this stage, removing $\mathrm{Ca}++$ from casein micelles would decrease its micellar size as $\mathrm{Ca}^{++}+$acts as the interacting nodes in the colloidal system of milk. This would reduce the relative viscosity of retentate. SAIto and Hirose (1972) found that the addition of $1 \mathrm{M} \mathrm{NaCl}$ to casein micelles, release 
part of the $\mathrm{Ca}^{++}$and solubilize part of the protein which support the present finding.

The relative viscosity of retentate with added $\mathrm{NaCl}$ was probably controlled by the two mentioned reactions and the relative viscosity would depend on the ratio of added salt/protein in retentates and the time lapsed from the addition of $\mathrm{NaCl}$.

The growth of starter bacteria in the retentate of different protein contents was accompanied with a decrease in $\mathrm{pH}$ and relative viscosity. This can be attributed to reduction in hydration of casein micelles (Soop et al., 1979). However, this does not exclude the possible proteolysis in casein by starter enzymes (LAWREANCE and Thomas, 1979) reducing the molecular size of casein micelles and consequently reducing their relative viscosities. At $\mathrm{pH}$ less than 6.00 , the relative viscosity of retentates reincreased again due to possible aggregation of altered casein through hydrophobic interactions forming large aggregates. AlBERTSEN et al. (1983) showed that the viscosity of UF retentate reach a minimum at $\mathrm{pH} 5.2$ and then reincreased. In the present study retentates were prepared from reconstituted skim milk. The presence of partially denatured whey proteins would modify the functional properties of retentates rendering them more sensitive to changes in $\mathrm{pH}$. The $\mathrm{pH}$ at which the relative viscosity started to reincrease was also affected by the percentage of added $\mathrm{NaCl}$. The higher the $\mathrm{NaCl}$ added, the lower the $\mathrm{pH}$ at which the relative viscosity of retentate began to reincrease. This can be explained on the basis that the increased ionic strength of the medium with added $\mathrm{NaCl}$ would increase the repulsive forces and delay aggregation of the altered casein micelles.

Reçu le 18 juillet 1985

Accepté pour publication le 3 juin 1986

\section{References}

ALBERTSEN K., KRISTENSEN S., MADSEN R.F., 1983. Rheological properties of ultrafiltered milk products and their importance to ultrafiltration process. In : Proceedings IDF Symposium "Physico-chemical aspects of dehydrated protein rich milk products ». Mai 1983, Hillerod, Denmark, 138-147.

Cultoli J., Bon J.P., Maubois J.L., 1974. Etude de la viscosité des " rétentats " et des "préfromages " obtenus après traitement du lait par ultrafiltration sur membrane. Lait, 54 (538), 481-500.

JENNESS R, SHIPE W.F. Jr., SHERBon J.W., 1974. Physical properties of milk. In : Fundamentals of dairy chemistry. Webb, Johnson and Alford ed., Avi Pub. Co. Westport, Connecticut (U.S.A.), 402-441.

LAWRENCE R.C., Thomas T.D., 1979. The fermentation of milk by lactic acid bacteria. In : Microbial technology. Ellwood and Ratledge ed., Society of General Microbiology, Ltd., UK, 187-219.

Pierre A., Brule G., Fauquant J., 1978. Influence des traitements thermiques sur les propriétés physicochimiques des rétentats obtenus par ultrafiltration du lait de vache et de chèvre. II. Modifications des propriétés rhéologiques du lait de vache. Lait, 59 (579-580), 574-594.

SaIto Z., Hirose M., 1972. Some properties of centrifugally fractionated casein micelles of cow's milk. Bull. Fac. Agric., Horosaki Univ., Jpn, 18, 35.

Sood S.M., SIDER K.S., Dewan R.K., 1979. Effect of pH on micellar solvation and heat stability of milk from buffalo and cow. Indian J. Dairy Sci., 32, 458-460. 